\title{
Comparative Assessment of the NPP Risk (on the Example of Rostov and Kalinin NPP). Development of Risk Indicators Atlas for Russian NPPs
}

\author{
K.I. Chernyavskii ${ }^{1}$, M.A. Berberova ${ }^{2}$ \\ kirill.chernyavskiy@rambler.ru|maria.berberova@gmail.com \\ ${ }^{1}$ Moscow Institute of Physics and Technology, Moscow, Russia; \\ ${ }^{2}$ International Nuclear Safety Center, Moscow, Russia
}

The object of the work is to compare and analyze external and internal exposure doses and assess damage to the population living around nuclear power plants with VVER-type reactors (on the Rostov and Kalinin nuclear power plants), within a certain radius, taking into account the wind rose. There will also be proposed measures for the possible addition and refinement of formulas. The method of calculating the doses of external and internal exposure, as well as damage to the population in the ring segment of rumba. External and internal exposure doses for Kalinin and Rostov NPPs have been considered. An assessment of material damage was conducted. A variant of the format of the atlas of risk assessments is proposed. Initial assumptions have been made regarding the discrepancy in the results obtained for both doses and damage. One of the possible reasons for the discrepancy in the results of calculating the dose and damage to the Kursk and Smolensk NPPs may be the difference in the terrain. We need to take this into account. By relief changes we mean not ravines and slopes, but hills, mountains, fields. Additionally, you can consider the type of terrain: steppes, forests, etc., although all this will contribute to the already quite a long distance from the nuclear power plant. In the future, it is planned to continue work on the atlas of risk assessments and think over its more convenient format.

Keywords: Irradiation; dose; NPP; damage; population; safety data sheet; risk assessment atlas.

\section{Introduction}

The accident at the Chernobyl nuclear power plant was an event of great social and political significance for the USSR. All this left a definite imprint on the course of the investigation of its causes. The approach to the interpretation of the facts and circumstances of the accident has changed over time, and there is still no complete consensus.

But still the most important thing is people. If we learn to accurately assess the damage that a nuclear power plant can cause in the first moments after the accident, we will significantly reduce the number of victims among the population Comparative risk assessment in an accident at various NPPs gives an idea of the relationship between the amount of damage and external factors (location, climatic conditions, etc.), in this case, the wind rose.

This assessment is relevant, since all nuclear power plants are sources of potential danger. According to the Order of the EMERCOM of Russia of 04.11.2004 No. 506 [1], it is necessary to carry out work on risk assessment at relevant facilities. In this regard, the definition and comparison of the risk of an Emergency Accident (EA) at a nuclear power plant is a relevant topic.

According to Russian legislation (for example, [2]), the development of a facility safety data sheet is a prerequisite for the operation of such facilities as: hydraulic structures, organizations producing, processing, storing or transporting radioactive, fire and explosive, toxic chemical and biological substances (filling stations, thermal power plants, nuclear power plants, industrial enterprises, etc.), as well as those characterized by an increased risk of terrorist actions (crowded places).

This work is based on the study, further comparison and analysis of the estimates obtained in the calculations for two NPPs: Kalinin and Rostov. A comparative assessment has not previously been carried out, but it will help to understand what factors play a key role in the event of an accident. In this connection, two similar nuclear power plants were chosen: Kalinin and Rostov. They are of the same type and can give us a complete Figure for evaluation.

Rostov NPP is located in the Rostov region, $12 \mathrm{~km}$ from the city of Volgodonsk on the bank of the Tsimlyansk reservoir.

The electrical capacity of the four existing power units is 4.03 GW.

Kalinin NPP is located in the north of the Tver region, 120 $\mathrm{km}$ from the city of Tver. Distance to Moscow - $360 \mathrm{~km}$, to St.
Petersburg - $320 \mathrm{~km}$. The NPP site is located on the southern shore of Lake Udomlya and near the city of the same name. The total area occupied by KAES is 287.37 hectares.

The electrical power of the four operating units is $4 \mathrm{GW}$.

\section{Materials and methods}

Comparative assessment of risk indicators will be made based on the formulas proposed in [6]. Damage to one person living in the ring segment of rumba:

$$
L(R)=\frac{L_{\Sigma}}{N_{\Sigma}} \cdot \frac{\int_{0}^{R} D_{E}(r) \cdot N_{\frac{1}{8}}(r) \cdot d r}{\left.D_{E(\text { year }}\right)},
$$

where: $\mathrm{L} \quad-$ damage to the population in the rumba ring segment;

$\mathrm{R}, \mathrm{r} \quad$ - distance from NPP;

$\mathrm{L} \Sigma \quad$ - total damage from an accident;

$\mathrm{N}_{\Sigma} \quad-$ total population;

$\mathrm{DE}_{\mathrm{E}}$ - annual effective radiation dose of the population in the ring segment of rumba, considering the wind rose;

$\mathrm{N}_{1 / 8}$ - number of people in rumba;

$D_{E(y e a r)}$ - annual effective dose to the entire population.

Risk:

$$
R=\sum_{i=1}^{n} k \cdot F_{i} \cdot D_{i}<R_{a}
$$

where: $\quad \mathrm{Ra} \quad-\quad$ risk acceptable, 1/year

$$
\begin{aligned}
\mathrm{F} \quad-\quad \begin{array}{l}
\text { probability (frequency) of dangerous } \\
\text { situations; }
\end{array} \\
\mathrm{D} \quad-\quad \begin{array}{l}
\text { the level of the corresponding dangerous } \\
\text { effects on people; }
\end{array} \\
\mathrm{k} \quad-\quad \begin{array}{l}
\text { coefficient linking the probability } \\
\text { (frequency) of death to people with }
\end{array} \\
\begin{array}{l}
\text { dangerous effects }(5,6 \cdot 10-21 / \mathrm{Sv} \text { in } \\
\text { accordance with [6]). }
\end{array}
\end{aligned}
$$

The annual effective radiation dose of the population in the ring segment of rumba, taking into consideration the wind rose:

$$
D_{E}(R)=P_{W} \cdot \sum_{i=1}^{k} N_{\frac{1}{8}(i)} \cdot D_{E(\text { year })(i)},
$$

where: DE - annual effective radiation dose of the population in the ring segment of rumba, considering the wind rose;

$\mathrm{R} \quad-\quad$ distance from NPP;

$\mathrm{P}_{\mathrm{W}} \quad-\quad$ wind direction probability;

$\mathrm{N}_{1 / 8} \quad-\quad$ number of people in rumba; 


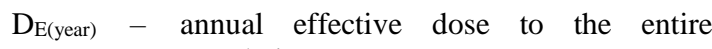
population.

\section{Literature Review}

We have an opportunity to work with the whole point, but priority is given to the directions with the highest probability of the wind. For Rostov NPP: East direction (probability 0.2). For Kalinin NPP: South-West direction (probability 0.18).

Let us calculate the annual effective radiation dose for the Rostov NPP $(\mathrm{mSv})$. The baseline data and the results of calculating the annual effective radiation dose for the Rostov NPP are presented in Table. 1 [7].

Table 1. Baseline data and the results of calculating the annual effective radiation dose of the population for the Rostov NPP

\begin{tabular}{|c|c|c|c|c|}
\hline$R$ & $P_{w}$ & $N_{I / 8(i)}$ & $D_{E(\text { year })(i)}$ & $D_{E}$ \\
\hline 3 & 0,2 & 0 & 0 & 0 \\
\hline 10 & 0,2 & 860 & 10,5 & 1806 \\
\hline 15 & 0,2 & 0 & 1,91 & 0 \\
\hline 20 & 0,2 & 620 & 1,04 & 128 \\
\hline 30 & 0,2 & 512 & 0,6 & 61 \\
\hline 40 & 0,2 & 1044 & 0,32 & 66 \\
\hline 50 & 0,2 & 1342 & 0,2 & 54 \\
\hline 100 & 0,2 & 11186 & 0,1 & 234 \\
\hline
\end{tabular}

Let us calculate the annual effective radiation dose of the population for Kalinin NPP (mSv). The baseline data and the results of calculating the annual effective radiation dose for the population of Kalinin NPP are presented in Table 2 [7].

Table 2. Baseline data and the results of calculating the annual effective radiation dose for the population of Kalinin NPP

\begin{tabular}{|c|c|c|c|c|}
\hline$R$ & $P_{w}$ & $N_{l / 8(i)}$ & $D_{E(\text { year })(i)}$ & $D_{E}$ \\
\hline 3 & 0,18 & 16158 & 34 & 98887 \\
\hline 10 & 0,18 & 318 & 13 & 744 \\
\hline 15 & 0,18 & 230 & 4,6 & 190 \\
\hline 20 & 0,18 & 598 & 2,4 & 258 \\
\hline 30 & 0,18 & 363 & 1 & 65 \\
\hline 40 & 0,18 & 26349 & 1 & 4742 \\
\hline 50 & 0,18 & 52342 & 0,61 & 5747 \\
\hline 100 & 0,18 & 26511 & 0,21 & 1002 \\
\hline
\end{tabular}

It can be seen that the radiation dose for Kalinin NPP is significantly higher than for Rostov. Firstly, this is due, of course, to the number of people who live around the NPP data. If we look at the data for the Kalinin NPP, we note that from the direction of the most possible wind direction at a distance of $3 \mathrm{~km}$ from the NPP there is a very large number of people: 16158 people. As for the Rostov NPP, no one lives from the direction of the most possible wind direction at a distance of $3 \mathrm{~km}$ from the NPP. Secondly, Kalininskaya and Rostov NPP have approximately the same values for DE (year), but there is a rather large difference in the relief, which can lead to completely different consequences. Most of the territory of the Rostov NPP has a flat and flat relief character. Agricultural production predominates in this area. Arable land is crossed by forest belts of 15-20 m, planted mainly by forest forest strata. Rostov NPP is located in the continental climate zone, with insufficient moisture, hot and dry summers, and relatively long and cold winters. A distinctive feature of the climate is the abundance of sun and heat. Unlike the relief of the territory of the Rostov NPP [7], the territory of the Kalinin NPP has a dissected relief, the prevalence of absolute heights and small relief forms. In the middle part of the region, from the southwest to the northeast, there are uplifts of the Forest Ridge, which is a spur of the Valdai Upland [7]. The forest ridge is divided by two large zandrovaya plains: in the east Srednemozhskaya nisin with absolute heights of 130-140 m, in the west and south - Vyshnevolotskaya nisin with heights of 150$180 \mathrm{~m}[4,5,9-11]$.

In more detail this issue will be considered later.

\section{Comparative damage assessment for Kalinin and Rostov NPPs}

For damage assessment, as well as for comparative assessment of external and internal exposure doses, we will consider the most dangerous accident. These data additionally give an idea of the situation around the Kalinin and Rostov NPPs.

The calculation will be made by the formula (1). As can be seen from the formula, we will need the data obtained earlier in the calculation of doses using formula (3) and presented in Table 1 and 2 [7].

Immediately, we note that the damage for Kalinin NPP, presented in [5], is significantly higher than for Rostov [4], which partially confirms our formula and conclusions made on the basis of a comparative assessment for doses of external and internal exposure.

First, perform the calculations for the Rostov NPP.

L (for the Rostov NPP at a distance of 10, 30 and $100 \mathrm{~km}$ from the NPP):

$\mathrm{L}(10)=0,04$ million rubles

$\mathrm{L}(30)=0,84$ million rubles

$\mathrm{L}(100)=5,87$ million rubles

$\mathrm{L}$ (for Kalinin NPP at a distance of 10, 30 and $100 \mathrm{~km}$ from the NPP):

$\mathrm{L}(10)=7,66$ million rubles

$\mathrm{L}(30)=100,14$ million rubles

$\mathrm{L}(100)=531,59$ million rubles

Again, we get an excess of the Kalinin NPP. This excess has a logical explanation. The population is one of the main indicators for damage. Since the main costs fall on the people and property that these people possess. Of course, errors are permissible, since For the Kalinin and Rostov nuclear power plants, calculations were made taking into account the most probable wind direction, but these errors do not change the overall Figure.

\section{Formation risk indicators assessments atlas of Russian NPP units}

Calculation of damage to the population in the ring segment of rumba, as a result of exposure to radioactive substances, was carried out according to formula (1) [6-11].

The calculation of the annual effective radiation dose of the population in the ring segment of rumba, taking into account the wind rose, was carried out according to the formula (3) [6-11].

In [10], an example of an atlas format of risk indicator estimates is proposed.

For power units with RBMK-1000 type reactors (Kursk and Smolensk NPP) - Table. 3-14, fig. 1-6.

Table 3. Indicators of radiation risk for the population from accidents at the Kursk NPP

\begin{tabular}{|c|c|c|}
\hline $\begin{array}{c}\text { Average individual } \\
\text { effective dose for } \\
\text { population Ei, Sv }\end{array}$ & $\begin{array}{c}\text { Individual risk of death of } \\
\text { the population (long-term } \\
\text { effects) rc, (for 1 accident) }\end{array}$ & $\begin{array}{c}\text { Individual risk of the } \\
\text { population death rci, 1/year } \\
\text { (considering EA frequency) }\end{array}$ \\
\hline $2.5 \cdot 10^{-4}$ & $1.25 \cdot 10^{-5}$ & $8.75 \cdot 10^{-13}$ \\
\hline
\end{tabular}

Table 4. Indicators of the economic risk to the population from accidents at the Kursk NPP

\begin{tabular}{|c|c|c|}
\hline $\begin{array}{c}\text { Population, } \\
\text { people }\end{array}$ & $\begin{array}{c}\text { Collective dose for population, } \\
\text { people } \cdot \text { Sv }\end{array}$ & $\begin{array}{c}\text { Damage to the population, } \\
\text { mln. rub. }\end{array}$ \\
\hline 1365132 & 339 & 102 \\
\hline
\end{tabular}

Table 5. Probability of the direction of propagation of radioactive substances in the cardinal directions at the Kursk NPP

\begin{tabular}{|c|c|}
\hline Rumb & Wind direction repeatability, \% \\
\hline North & 5,5 \\
\hline Northeast & 4,9 \\
\hline
\end{tabular}




\begin{tabular}{|c|c|}
\hline Rumb & Wind direction repeatability, \% \\
\hline East & 16,5 \\
\hline Southeast & 9,1 \\
\hline South & 15,9 \\
\hline Southwest & 10,4 \\
\hline West & 28,7 \\
\hline Northwest & 9 \\
\hline Total & 100 \\
\hline
\end{tabular}

Figure 1 is a diagram of the frequency of wind direction at the Kursk NPP [10].

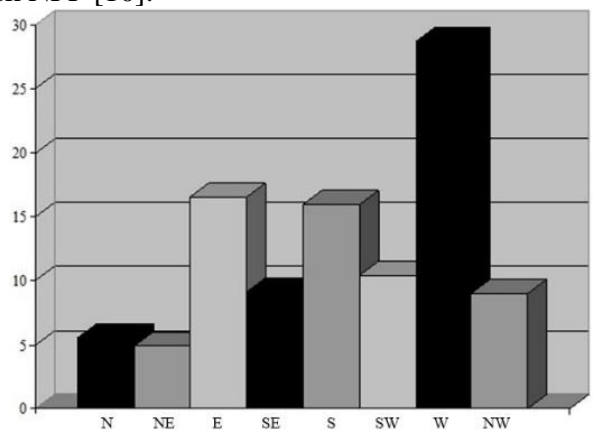

Figure 1. Diagram of the frequency of wind direction at the Kursk NPP

Table 6. Population distribution in the $100-\mathrm{km}$ zone of the Kursk NPP

\begin{tabular}{|c|c|c|c|c|c|c|c|c|}
\hline \multirow{2}{*}{ Rumb } & \multicolumn{8}{|c|}{ Distance from NPP, km } \\
\cline { 2 - 10 } & $3-5$ & $5-10$ & $10-15$ & $15-20$ & $20-30$ & $30-40$ & $40-50$ & $50-100$ \\
\hline North & 467 & 224 & 184 & 755 & 1661 & 7700 & 9880 & 82432 \\
\hline Northeast & - & 636 & 600 & 2303 & 4853 & 7700 & 9880 & 82432 \\
\hline East & - & 2471 & 941 & 1953 & 20631 & 7700 & 408000 & 82432 \\
\hline Southeast & 46500 & 120 & 649 & 3114 & 5695 & 7700 & 9880 & 82432 \\
\hline South & - & 3346 & 321 & 1260 & 1352 & 7700 & 9880 & 82432 \\
\hline Southwest & - & 10552 & 371 & 2010 & 6900 & 7700 & 9880 & 82432 \\
\hline West & - & 435 & 330 & 1303 & 29779 & 7700 & 9880 & 82432 \\
\hline Northwest & 685 & 124 & 238 & 1808 & 12345 & 7700 & 9880 & 82432 \\
\hline Total & 47652 & 17908 & 3634 & 14506 & 83216 & 61600 & 477160 & 659456 \\
\hline TOTAL & \multicolumn{870}{|c|}{1365132} \\
\hline
\end{tabular}

Table 7. The results of the calculation of the annual effective radiation dose of one person and the entire population living in the ring segment of rumba, taking into account the wind rose, at a distance of 3-30 km from the nuclear power plant for Kursk NPP with an RBMK-1000 type reactor

\begin{tabular}{|c|c|c|c|}
\hline Rumb & $\begin{array}{c}\text { Annual effective dose of } \\
\text { one person taking into } \\
\text { account wind rose (Sv) }\end{array}$ & $\begin{array}{c}\text { Number of } \\
\text { people }\end{array}$ & $\begin{array}{l}\text { Collective radiation dose of } \\
\text { the population in the ring } \\
\text { segment of rumba (man-Sv) }\end{array}$ \\
\hline \multicolumn{4}{|c|}{$3-10 \mathrm{~km}$} \\
\hline South & $2.3 \cdot 10^{-4}$ & 3346 & 0.76 \\
\hline Southwest & $2.0 \cdot 10^{-4}$ & 10552 & 2.14 \\
\hline West & $6.8 \cdot 10^{-4}$ & 435 & 0.30 \\
\hline Northwest & $3.8 \cdot 10^{-4}$ & 809 & 0.30 \\
\hline North & $6.6 \cdot 10^{-4}$ & 691 & 0.45 \\
\hline Northeast & $4.3 \cdot 10^{-4}$ & 636 & 0.27 \\
\hline East & $1.2 \cdot 10^{-3}$ & 2471 & 2.93 \\
\hline Southeast & $3.7 \cdot 10^{-4}$ & 46620 & 17.34 \\
\hline \multicolumn{4}{|c|}{$10-15 \mathrm{~km}$} \\
\hline South & $3.0 \cdot 10^{-5}$ & 321 & 0.01 \\
\hline Southwest & $2.0 \cdot 10^{-5}$ & 371 & 0.01 \\
\hline West & $8 \cdot 10^{-5}$ & 330 & 0.02 \\
\hline Northwest & $4 \cdot 10^{-5}$ & 238 & 0.01 \\
\hline North & $7 \cdot 10^{-5}$ & 184 & 0.01 \\
\hline Northeast & $5 \cdot 10^{-5}$ & 600 & 0.03 \\
\hline East & $1.3 \cdot 10^{-4}$ & 941 & 0.12 \\
\hline Southeast & $4 \cdot 10^{-5}$ & 649 & 0.03 \\
\hline \multicolumn{4}{|c|}{$15-20 \mathrm{~km}$} \\
\hline South & $10^{-5}$ & 1260 & 0.02 \\
\hline Southwest & $10^{-5}$ & 2010 & 0.02 \\
\hline West & $4 \cdot 10^{-5}$ & 1303 & 0.05 \\
\hline Northwest & $2 \cdot 10^{-5}$ & 1808 & 0.04 \\
\hline North & $4 \cdot 10^{-5}$ & 755 & 0.03 \\
\hline Northeast & $3 \cdot 10^{-5}$ & 2303 & 0.06 \\
\hline East & $7 \cdot 10^{-5}$ & 1953 & 0.14 \\
\hline Southeast & $2 \cdot 10^{-5}$ & 3114 & 0.07 \\
\hline \multicolumn{4}{|c|}{$20-30 \mathrm{~km}$} \\
\hline South & $10^{-5}$ & 1352 & 0.01 \\
\hline Southwest & $10^{-5}$ & 6900 & 0.05 \\
\hline West & $2 \cdot 10^{-5}$ & 29779 & 0.72 \\
\hline
\end{tabular}

\begin{tabular}{|c|c|c|c|}
\hline Rumb & $\begin{array}{c}\text { Annual effective dose of } \\
\text { one person taking into } \\
\text { account wind rose (Sv) }\end{array}$ & $\begin{array}{c}\text { Number of } \\
\text { people }\end{array}$ & $\begin{array}{c}\text { Collective radiation dose of } \\
\text { the population in the ring } \\
\text { segment of rumba (man-Sv) }\end{array}$ \\
\hline Northwest & $10^{-5}$ & 12345 & 0.17 \\
\hline North & $2 \cdot 10^{-5}$ & 1661 & 0.04 \\
\hline Northeast & $2 \cdot 10^{-5}$ & 4853 & 0.07 \\
\hline East & $4 \cdot 10^{-5}$ & 20631 & 0.87 \\
\hline Southeast & $10^{-5}$ & 5695 & 0.08 \\
\hline
\end{tabular}

Figure 2 shows a graphical representation of the results of calculating the annual effective doses of exposure of one person and the entire population living in the ring segment of rumba, taking into account the wind rose, for Kursk NPP [10].

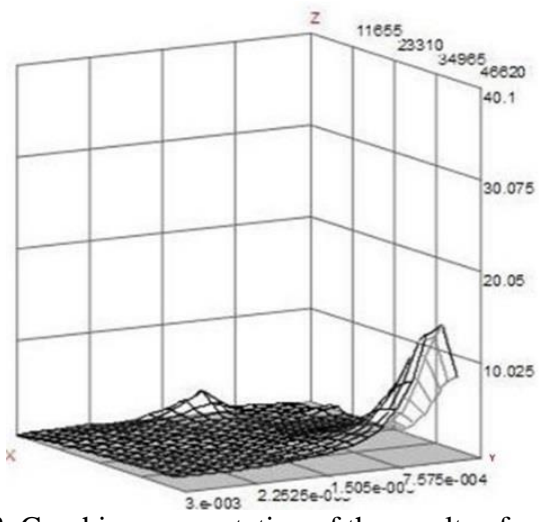

Figure 2. Graphic representation of the results of calculating the annual effective doses of exposure to one person and the entire population living in the ring segment of rumba, taking into account the wind rose, for the Kursk NPP

Table 8. The results of the calculation of damage to one person living in the ring segment of rumba, at a distance of 3-30 km from the nuclear power plant for Kursk NPP

\begin{tabular}{|c|c|c|}
\hline Rumb & $\begin{array}{l}\text { Number of } \\
\text { people }\end{array}$ & $\begin{array}{l}\text { Damage to one person in the ring } \\
\text { segment of rumba, rub. }\end{array}$ \\
\hline \multicolumn{3}{|c|}{$3-10 \mathrm{~km}$} \\
\hline South & 3346 & 2.7 \\
\hline Southwest & 10552 & 2.4 \\
\hline West & 435 & 8.2 \\
\hline Northwest & 809 & 4.5 \\
\hline North & 691 & 7.9 \\
\hline Northeast & 636 & 5.2 \\
\hline East & 2471 & 14 \\
\hline Southeast & 46620 & 4.5 \\
\hline \multicolumn{3}{|c|}{$10-15 \mathrm{~km}$} \\
\hline South & 321 & 2.7 \\
\hline Southwest & 371 & 2.4 \\
\hline West & 330 & 8.2 \\
\hline Northwest & 238 & 4.5 \\
\hline North & 184 & 7.9 \\
\hline Northeast & 600 & 5.2 \\
\hline East & 941 & 14 \\
\hline Southeast & 649 & 4.5 \\
\hline \multicolumn{3}{|c|}{$15-20 \mathrm{~km}$} \\
\hline South & 1260 & 2.8 \\
\hline Southwest & 2010 & 2.4 \\
\hline West & 1303 & 8.3 \\
\hline Northwest & 1808 & 4.5 \\
\hline North & 755 & 7.9 \\
\hline Northeast & 2303 & 5.1 \\
\hline East & 1953 & 14 \\
\hline Southeast & 3114 & 4.5 \\
\hline \multicolumn{3}{|c|}{$20-30 \mathrm{~km}$} \\
\hline South & 1352 & 2.7 \\
\hline Southwest & 6900 & 2.4 \\
\hline West & 29779 & 8.2 \\
\hline Northwest & 12345 & 4.4 \\
\hline North & 1661 & 7.8 \\
\hline Northeast & 4853 & 5.1 \\
\hline East & 20631 & 0.1 \\
\hline Southeast & 5695 & 4.4 \\
\hline
\end{tabular}


Figure 3 shows a graphical representation of the results of calculating the damage caused to one person and the entire population living in the ring segment of rumba, at a distance of 3-30 km from the NPP for Kursk NPP [10].

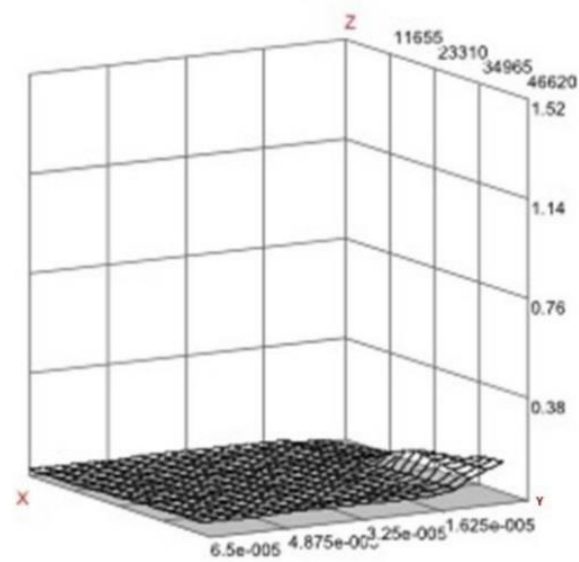

Figure 3. Graphic representation of the results of calculating the damage caused to one person and the entire population living in the ring segment of rumba, at a distance of 3-30 km from the NPP for Kursk NPP

Table 9. Indicators of radiation risk from accidents at Smolensk NPP

\begin{tabular}{|c|c|c|}
\hline $\begin{array}{c}\text { Average individual } \\
\text { effective dose of } \\
\text { the population Ei, } \\
\mathrm{Sv}\end{array}$ & $\begin{array}{c}\text { Individual risk of death } \\
\text { of the population (long- } \\
\text { term effects) rc, (for 1 } \\
\text { accident) }\end{array}$ & $\begin{array}{c}\text { Individual risk of the } \\
\text { population death rci, 1/ } \\
\text { year (including EA } \\
\text { frequency) }\end{array}$ \\
\hline $1.3 \cdot 10^{-3}$ & $6.4 \cdot 10^{-5}$ & $4.5 \cdot 10^{-12}$ \\
\hline
\end{tabular}

Table 10. Indicators of the economic risk from accidents at Smolensk NPP

\begin{tabular}{|c|c|c|}
\hline Population & $\begin{array}{c}\text { Collective dose of the } \\
\text { population, people } \cdot \text { Sv }\end{array}$ & $\begin{array}{c}\text { Damage to the } \\
\text { population, mln. rub. }\end{array}$ \\
\hline 257412 & 330 & 99 \\
\hline
\end{tabular}

Figure 4 is a diagram of the frequency of wind direction at Smolensk NPP [10].

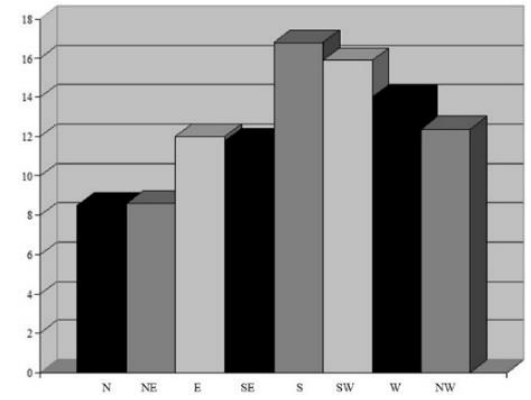

Figure 4. Diagram of the frequency of wind direction at Smolensk NPP

Figure 5 shows a graphical representation of the results of calculating the annual effective doses of exposure to one person and the entire population living in the ring segment of rumba, taking into account the wind rose, for the second stage of the Smolensk NPP [10].

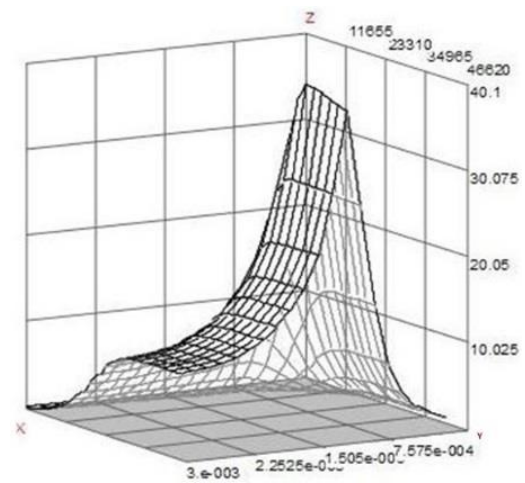

Figure 5. A graphic representation of the results of calculating the annual effective radiation doses of one person and the entire population living in the ring segment of rumba, taking into account the wind rose, for Smolensk NPP

Table 11. The results of the calculation of damage to one person living in the ring segment of rumba, at a distance of 3-30 $\mathrm{km}$ from the nuclear power plant for Smolensk NPP

\begin{tabular}{|c|c|c|}
\hline Rumb & $\begin{array}{c}\text { Number of } \\
\text { people }\end{array}$ & $\begin{array}{l}\text { Damage to one person in the ring } \\
\text { segment of rumba, mln. rub. }\end{array}$ \\
\hline \multicolumn{3}{|c|}{$3-10 \mathrm{~km}$} \\
\hline South & 0 & 0 \\
\hline Southwest & 0 & 0 \\
\hline West & 0 & 0 \\
\hline Northwest & 0 & 0 \\
\hline North & 0 & 0 \\
\hline Northeast & 0 & 0 \\
\hline East & 0 & 0 \\
\hline Southeast & 33000 & $4.6 \cdot 10^{-5}$ \\
\hline \multicolumn{3}{|c|}{$10-15 \mathrm{~km}$} \\
\hline South & 294 & $3.3 \cdot 10^{-5}$ \\
\hline Southwest & 294 & $3.3 \cdot 10^{-5}$ \\
\hline West & 294 & $4.6 \cdot 10^{-5}$ \\
\hline Northwest & 294 & $4.6 \cdot 10^{-5}$ \\
\hline North & 294 & $6.3 \cdot 10^{-5}$ \\
\hline Northeast & 294 & $6.0 \cdot 10^{-5}$ \\
\hline East & 294 & $5.3 \cdot 10^{-5}$ \\
\hline Southeast & 294 & $4.9 \cdot 10^{-5}$ \\
\hline \multicolumn{3}{|c|}{$15-20 \mathrm{~km}$} \\
\hline South & 412 & $3.3 \cdot 10^{-5}$ \\
\hline Southwest & 412 & $3.3 \cdot 10^{-5}$ \\
\hline West & 412 & $4.6 \cdot 10^{-5}$ \\
\hline Northwest & 412 & $4.6 \cdot 10^{-5}$ \\
\hline North & 412 & $6.5 \cdot 10^{-5}$ \\
\hline Northeast & 412 & $6.1 \cdot 10^{-5}$ \\
\hline East & 412 & $5.4 \cdot 10^{-5}$ \\
\hline Southeast & 412 & $4.8 \cdot 10^{-5}$ \\
\hline \multicolumn{3}{|c|}{$20-30 \mathrm{~km}$} \\
\hline South & 1176 & $3.3 \cdot 10^{-5}$ \\
\hline Southwest & 1176 & $3.3 \cdot 10^{-5}$ \\
\hline West & 1176 & $4.6 \cdot 10^{-5}$ \\
\hline Northwest & 1176 & $4.6 \cdot 10^{-5}$ \\
\hline North & 1176 & $6.5 \cdot 10^{-5}$ \\
\hline Northeast & 1176 & $6.2 \cdot 10^{-5}$ \\
\hline East & 1176 & $5.4 \cdot 10^{-5}$ \\
\hline Southeast & 1176 & $4.7 \cdot 10^{-5}$ \\
\hline
\end{tabular}

Figure 6 shows a graphical representation of the results of calculating the damage caused to one person and the entire population living in the ring segment of rumba, at a distance of 3-30 km from the NPP for Smolensk NPP [10]. 


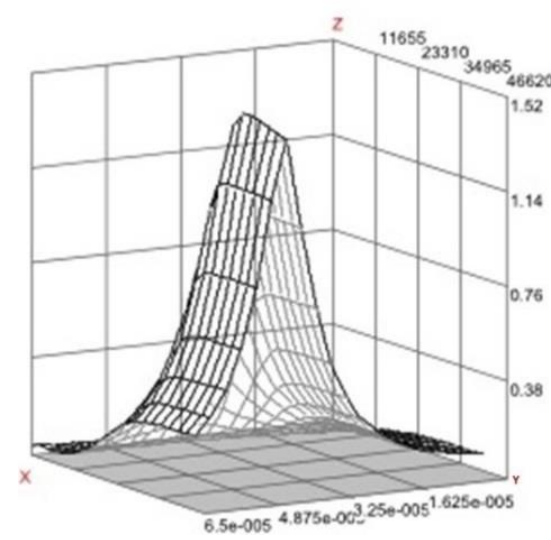

Figure 6. Graphic representation of the results of calculating the damage caused to one person and the entire population living in the ring segment of rumba, at a distance of 3-30 km from the NPP for Smolensk NPP

\section{Results}

At present, external and internal exposure doses for Kalinin and Rostov NPPs have been considered. An assessment of material damage was conducted. A variant of the format of the atlas of risk assessments is proposed. Initial assumptions have been made regarding the discrepancy in the results obtained for both doses and damage.

\section{Thanks}

The study was carried out within the framework of grant 1907-00455 «Development of models, algorithms and software for solving the problems of safety and risk assessment at nuclear power plants during beyond design basis accidents with the release of sources of thermal neutrons with low flux density».

\section{References:}

1. On approval of a typical safety data sheet of a hazardous object: [Order of the Emergencies Ministry of Russia No. 506 of November 4, 2004]. - M., 2004. - 1 p.

2. Safety data sheet of the critical (dangerous) object of Rosatom: [order of the Ministry of Emergency Situations of Russia No. 506 of November 4, 2004]. - M., 2006. - 9 p.

3. Methodology for assessing risk indicators for managing the safety of critical (hazardous) facilities of ROSATOM: [Methodology: Approved by the First Deputy Director General of the State Atomic Energy Corporation ROSATOM for the nuclear weapons complex on March 29, 2016]. - M., 2016. - 253 p.

4. Development of a list of safety management measures and assessment of risk indicators for NPPs with VVER-type reactors (Rostov NPP with a VVER-1000 reactor) / Kabanov L.P., Derevyankin A.A., Zhukov I.V., Chulkova E.V., Berberova M.A. - M.: International Nuclear Safety Center, 2010. - $132 \mathrm{p}$.

5. Development of a list of safety management measures and assessment of risk indicators for NPPs with VVER-type reactors (Kalinin NPP with a VVER-1000 reactor) / Berberova M.A., Zhukov I.V., Ivanov I.V., Chulkova Ye.V., Tsykalo N.B. - M .: International Nuclear Safety Center, 2012. - 109 p.

6. Berberova M.A. Assessment of risk indicators for the second stages of Smolensk and Kursk NPP: dissertation for the degree of candidate of technical sciences: 05.14.03 / Berberova Maria Aleksandrovna. - M., 2015. - 130 p.

7. Maksimov A.S., Berberova M.A., "Comparative assessment of external and internal radiation doses and assessment of damage to the population living around NPPs with WWER-type reactors (using the example of Rostov and Kalinin NPPs)" / Maksimov A.S., Berberova M.A. // CPT-2017: Proceedings of the International Scientific Conference - Protvino-Moscow: Ed. ICPT - P. 257-260.

8. Berberova M.A., Islamov R.T., Zaripov I.R., Lipatov A.A., Lebedev K.Yu., Gridnev A.A., Burkhonov R.A., Voshchan I.O. Evaluation of risk indicators for NPPs with BN-600 and RBMK-1000 type reactors // Proceedings of the International Conference and Schools on the Resilience of Sociotechnical Systems "Resilience2014", November 2528, 2014, Protvino, Drakino Park, Moscow Region. - Ed. ICPT, Protvino-Moscow, 2015, ISBN 978-5-88835-037-9, P.179-185.

9. Bykov N.K., Zolotarev S.S., Chernyavsky K.I., Berberova M.A. Development of an atlas of risk indicators for Russian NPPs / N.K. Bykov, S.S. Zolotarev, K.I. Chernyavsky, M.A. Berberova // SCVRT2017: proceedings of the International Scientific Conference. - Protvino-Moscow: Ed. ICPT. - p. 85-89.

10. Chernyavsky K.I., Bykov N.K., Zolotarev S.S., Berberova M.A. "Development of an Atlas of Estimates of Risk Indicators for Russian NPPs" // CPT-2018: proceedings of the International Scientific Conference. - ProtvinoMoscow: Ed. ICPT, p. 289-298.

11. Chernyavskiy K.I., Berberova M.A., Konstantinov M.V., Tsykalo V.A. Development of an atlas of safety data sheets for Russian NPPs // CPT2019 Proceedings of the International Scientific Conference. - Nizhny Novgorod, 2019: Ed. NNSUACE-SRCIPT, p. 209-216. 